\title{
Serotonergic Drugs and Valvular Heart Disease
}

\author{
Richard B. Rothman and Michael H. Baumann \\ Clinical Psychopharmacology Section, Intramural Research Program, National Institute on Drug \\ Abuse, National Institutes of Health, DHHS, Baltimore, MD, USA
}

\begin{abstract}
Background-The serotonin (5-HT) releasers ( \pm )-fenfluramine and (+)-fenfluramine were withdrawn from clinical use due to increased risk of valvular heart disease. One prevailing hypothesis (i.e., the "5-HT hypothesis") suggests that fenfluramine-induced increases in plasma 5-HT underlie the disease.
\end{abstract}

Objective-Here we critically evaluate the possible mechanisms responsible for fenfluramineassociated valve disease.

Methods-Findings from in vitro and in vivo experiments performed in our laboratory are reviewed. The data are integrated with existing literature to address the validity of the 5-HT hypothesis and suggest alternative explanations.

Conclusions-The overwhelming majority of evidence refutes the 5-HT hypothesis. A more likely cause of fenfluramine-induced valvulopathy is activation of 5- $\mathrm{HT}_{2 \mathrm{~B}}$ receptors on heart valves by the metabolite norfenfluramine. Future serotonergic medications should be designed to lack 5- $\mathrm{HT}_{2 \mathrm{~B}}$ agonist activity.

\section{Introduction}

5-Hydroxytryptamine (5-HT or serotonin) is an important cell-to-cell signaling molecule found in all animal phyla ${ }^{1}$. In mammals, substantial concentrations of 5-HT are present in the central and peripheral nervous systems, gastrointestinal tract and cardiovascular system. 5-HT is capable of exerting a wide variety of biological effects by interacting with specific membranebound receptors, and at least 13 distinct 5-HT receptor subtypes have been cloned and characterized ${ }^{2}$. With the exception of the $5-\mathrm{HT}_{3}$ receptor subtype, which is a transmitter-gated ion channel, 5-HT receptors are members of the 7-transmembrane $\mathrm{G}$ protein-coupled receptor superfamily ${ }^{3}$. In humans, the serotonergic system is implicated in various physiological processes such as sleep-wake cycles, maintenance of mood, control of food intake and regulation of blood pressure. Accordingly, drugs that affect 5-HT-containing cells or 5-HT receptors are effective treatments for numerous indications, including depression, anxiety, obesity, nausea and migraine.

The 5-HT releasing agents $( \pm)$-fenfluramine $\left(\operatorname{Pondimin}^{\mathrm{TM}}\right)$ and $(+)$-fenfluramine $\left(\operatorname{Redux}{ }^{\mathrm{TM}}\right)$ were approved for the treatment of obesity by the U.S. Food and Drug Administration in 1973 and 1996, respectively. Both fenfluramines were subsequently withdrawn from the marketplace in 1997 because valvular heart disease (VHD) was discovered in some patients receiving these drugs 4,5 . Fenfluramine-associated VHD was characterized by thickening of valve leaflets and increased regurgitation of blood, most often detected by echocardiography. Initial findings from uncontrolled studies suggested that fenfluramines produce VHD in a high

Correspondence: Richard B. Rothman M.D., Ph.D., Chief, Clinical Psychopharmacology Section, IRP/NIDA/NIH, 333 Cassell Drive, Suite 4500, Baltimore, Maryland 21224, USA, +1 443-740-2652 (phone), +1 443-740-2241 (fax), E-mail: rrothman@ mail.nih.gov. 
percentage of patients, but recent retrospective studies show a much lower risk than once feared. For example, two meta-analyses of available clinical data report an odds ratio of $\sim 2.2$ for the incidence of valvular regurgitation in patients exposed to fenfluramines 6,7 . Additionally, the echocardiographic abnormalities in fenfluramine patients are often not accompanied by clinically significant symptoms of VHD 8,9 . Some investigators have suggested that the lack of clinically significant symptoms might be related to an adaptive dilatation of the heart chamber, a condition which responds well to the utilization of ACE inhibitors ${ }^{10}$. Most evidence indicates that the prevalence of VHD increased with both longer duration of fenfluramine treatment and higher doses administered ${ }^{11}$. One recent report suggests that patients with a history of fenfluramine treatment have higher rates of surgery for VHD when compared to the general population 12 .

Without question there were some fenfluramine-treated patients who were afflicted with severe VHD. When heart valves from these patients were surgically removed and examined, they displayed intact valve architecture with a glistening white appearance and plaque-like encasement of the leaflets and chordal structures. The unique heart valve abnormalities in these patients resembled those seen in carcinoid syndrome, a disease caused by 5-HT-secreting tumors. Because fenfluramines are potent 5-HT releasers 13, 14 and 5-HT has established mitogenic effects 15,16 , investigators initially suspected that serotonergic mechanisms were involved in the pathogenesis of fenfluramine-associated VHD. While many patients were treated with the combination of phentermine plus fenfluramine (i.e., "phen/fen"), no data have linked phentermine treatment alone with VHD, and this medication remains available for the clinical management of obesity. Additionally, there is no evidence to support the notion that phentermine-induced release of NE would have a synergistic effect on the serotonergic actions of fenfluramine ${ }^{17}$. At the present time, most data support the hypothesis that fenfluramineassociated VHD is related to the activation of 5- $\mathrm{HT}_{2 \mathrm{~B}}$ receptors by norfenfluramine, the main metabolite of fenfluramine (for review see: ${ }^{18}$ ). The purpose of the present article is to: 1 ) review the basic pharmacology of fenfluramine and norfenfluramine, 2) discuss the effects fenfluramine on circulating levels of 5-HT, and 3) consider the evidence supporting a role for $5-\mathrm{HT}_{2 \mathrm{~B}}$ receptors in mediating VHD associated with the use of fenfluramines and other serotonergic medications.

\section{Pharmacology of Fenfluramines}

It is well established that fenfluramines stimulate 5-HT transmission in the central nervous system ${ }^{19}$. Specifically, these agents increase extracellular levels of 5-HT in nervous tissue by a mechanism involving 5-HT transporter proteins (SERT) 13,20 . Drugs that interact with SERT, or other membrane-bound transporter proteins, can be divided into two classes: uptake inhibitors and substrate-type releasers. Uptake inhibitors bind to transporter proteins but are not transported. These drugs increase extracellular concentrations of neurotransmitters by interfering with neurotransmitter uptake from the synaptic cleft. Substrates also bind to transporters, but these compounds are subsequently translocated into nerve terminals where they promote the release of intracellular neurotransmitters by a process of carrier-mediated exchange 21 . Most findings indicate that stereoisomers of $( \pm)$-fenfluramine and $( \pm)$ norfenfluramine increase extracellular 5-HT by acting as substrates for SERT (for review see 22 ). In vivo microdialysis studies confirm that 5 -HT release evoked by $( \pm)$-fenfluramine or (+)-fenfluramine is antagonized by pretreatment with the SERT uptake blocker fluoxetine $\left(\operatorname{Prozac}^{\mathrm{TM}}\right)$ 23, 24 .

Pharmacokinetic investigations have revealed that stereoisomers of $( \pm)$-fenfluramine are $N$ de-ethylated by liver enzymes to yield the metabolites, $(+)-$ and $(-)$-norfenfluramine 25 . In humans and animals receiving systemic $( \pm)$-fenfluramine, circulating concentrations of $(+)$ and (-)-norfenfluramine are similar to or greater than concentrations of fenfluramine itself 
25,26 . Moreover, stereoisomers of ( \pm )-fenfluramine and $( \pm)$ norfenfluramine cross the bloodbrain barrier to accumulate in the central nervous system. Thus, peripheral administration of $( \pm)$-fenfluramine gives rise to four distinct pharmacological agents with potential neurobiological activity.

We developed a high-throughput in vitro assay method that can be used to discriminate between drugs that act as transporter uptake inhibitors vs. substrate-type releasers. Using this method, it is possible to profile the mechanism of action of test drugs at SERT, norepinephrine (NE) transporters (NET) and dopamine (DA) transporters (DAT), using nearly identical assay conditions 27,28 . With few exceptions 29,30 , investigations examining the neuropharmacology of fenfluramines and norfenfluramines have focused on the serotonergic effects of these drugs (for review see ${ }^{22}$ ). For this reason, we studied the interaction of ( \pm )fenfluramine, $( \pm)$-norfenfluramine, and their stereoisomers, with SERT, NET and DAT using in vitro assays and in vivo microdialysis methods 14 .

As reported in Table 1, the predominant action of $( \pm)$-fenfluramine and its stereoisomers is to evoke 5-HT release. (+)-Fenfluramine releases $\left[{ }^{3} \mathrm{H}\right] 5-\mathrm{HT}$ with an $\mathrm{EC}_{50}$ value of $51.7 \mathrm{nM}$ whereas (-)-fenfluramine releases [3H]5-HT with an $\mathrm{EC}_{50}$ value of $147 \mathrm{nM}$, about a 3-fold difference in potency. In the $\left[{ }^{3} \mathrm{H}\right] \mathrm{NE}$ release assay, (+)-fenfluramine displays activity that is about 6 -fold weaker than its activity in the $\left[{ }^{3} \mathrm{H}\right] 5$-HT release assay. (-)-Fenfluramine is very weak in the NE release assay. Thus, $(-)$-fenfluramine is more selective than (+)-fenfluramine as a $\left[{ }^{3} \mathrm{H}\right] 5-\mathrm{HT}$ releaser, but $(-)$-fenfluramine is less potent. $( \pm)$-Fenfluramine and its stereoisomers are essentially inactive in the DA release assay.

( \pm )-Norfenfluramine and its stereoisomers are also potent 5-HT releasers. (+)-Norfenfluramine releases $\left[{ }^{3} \mathrm{H}\right] 5-\mathrm{HT}$ with an $\mathrm{EC}_{50}$ value of $59.3 \mathrm{nM}$, whereas (-)-norfenfluramine releases $\left[{ }^{3} \mathrm{H}\right]$ 5-HT with an $\mathrm{EC}_{50}$ of $287 \mathrm{nM}$. ( \pm -Norfenfluramine and its stereoisomers are much more potent at releasing $\left[{ }^{3} \mathrm{H}\right] \mathrm{NE}$ than fenfluramines. For example, $(+)$-norfenfluramine releases $\left[{ }^{3} \mathrm{H}\right] \mathrm{NE}$ with an $\mathrm{EC}_{50}$ value of $72.7 \mathrm{nM}$, compared to (+)-fenfluramine which releases $\left[{ }^{3} \mathrm{H}\right] \mathrm{NE}$ with an $\mathrm{EC}_{50}$ value of $302 \mathrm{nM}$ (see above). It is important to note that norfenfluramines release $\left[{ }^{3} \mathrm{H}\right] \mathrm{NE}$ and $\left[{ }^{3} \mathrm{H}\right] 5-\mathrm{HT}$ with roughly equivalent potency. Additionally, the potency of (+)norfenfluramine to evoke $\left[{ }^{3} \mathrm{H}\right] \mathrm{NE}$ release is similar to the potency of phentermine and (-)ephedrine, which are known NE-releasing agents. Norfenfluramines are weak releasers of $\left[{ }^{3} \mathrm{H}\right] \mathrm{DA}$, but in this regard norfenfluramines are more potent than fenfluramines.

We carried out in vivo microdialysis experiments in rat prefrontal cortex to examine the effects of (+)-fenfluramine and (+)-norfenfluramine on extracellular concentrations of 5-HT, NE and DA. The microdialysis data depicted in Fig. 1 demonstrate that (+)-fenfluramine produces dose-related increases in dialysate levels of all three monoamines in cortex. The stimulatory effect of (+)-fenfluramine on dialysate 5-HT is the predominant action of this drug, with 5-HT levels reaching about 1000 percent above baseline (10-fold increase) at a $1 \mathrm{mg} / \mathrm{kg}$ dose and about 2200 percent of baseline ( 22 -fold increase) at a $3 \mathrm{mg} / \mathrm{kg}$ dose. (+)-Fenfluramine-induced also increases extracellular NE, but this effect is 5 -fold lower in magnitude when compared to 5-HT effects. (+)-Fenfluramine is weak as a releaser of DA, and the drug is only effective at the high dose.

Similar to (+)-fenfluramine, (+)-norfenfluramine produces dose-related elevations in dialysate 5-HT, NE and DA in rat cortex. As shown in Fig. 2, the rise in extracellular 5-HT evoked by $(+)$-norfenfluramine is comparable in magnitude to that observed with (+)-fenfluramine. (+)Norfenfluramine increases dialysate NE levels to a greater extent than that observed with (+)fenfluramine. In contrast to (+)-fenfluramine, (+)-norfenfluramine evokes increases in extracellular DA that are similar in magnitude to its effect on extracellular NE. Interestingly, the ability of (+)-norfenfluramine to increase extracellular NE and DA is reduced by 
pretreatment with the NE uptake blocker nisoxetine, while increases in extracellular 5-HT are unaffected. The nisoxetine findings suggest the possibility that NET sites are involved in the release of cortical NE and DA produced by (+)-norfenfluramine.

Viewed collectively, our results emphasize the complex pharmacology of ( \pm )-fenfluramine. From a pharmacokinetic perspective, administration of $( \pm)$-fenfluramine generates four bioactive agents: (+)-fenfluramine, (-)-fenfluramine, (+)-norfenfluramine and (-)norfenfluramine. While these compounds are predominately 5-HT releasing agents, they all interact to some degree with NET and DAT at sufficient doses. We have previously proposed that substrate activity at SERT is one factor responsible for the increased incidence of primary pulmonary hypertension in patients who have taken fenfluramines 31 . Data presented here demonstrate that the interaction of norfenfluramines with SERT and NET may contribute significantly to the mechanism of systemically administered fenfluramine. Fenfluramines and norfenfluramines also display direct interactions at multiple 5-HT receptor subtypes. Activation of $5-\mathrm{HT}_{2 \mathrm{C}}$ receptors is thought to mediate the anorectic effects of fenfluramines, and (+)-norfenfluramine is probably involved in this effect due to its potent affinity for 5$\mathrm{HT}_{2 \mathrm{C}}$ receptors $32-37$. Accumulating evidence shows that activation of $5-\mathrm{HT}_{2 \mathrm{~B}}$ receptors underlies VHD associated with ( \pm )-fenfluramine and (+)-fenfluramine 38,39 and also might contribute to the development of pulmonary hypertension 40 .

\section{Effect of Fenfluramines on Plasma 5-HT}

As noted in the Introduction, clinical investigators initially speculated that serotonergic mechanisms were involved in the pathogenesis of VHD in fenfluramine-treated patients ${ }^{4}$. In particular, it has been known for many years that high concentrations of plasma 5-HT are related to VHD in carcinoid syndrome. Given the histopathological similarities between the heart valves from carcinoid patients and those from fenfluramine-treated patients, it seemed logical to assume that elevations in plasma 5-HT could be responsible for fenfluramineassociated VHD. This hypothesis, termed the "5-HT hypothesis" of VHD, postulates that fenfluramine administration increases plasma 5-HT to concentrations which are sufficient to produce mitogenesis and subsequent valvular damage ${ }^{41}$. Thus, the effect of fenfluramine on plasma 5-HT is an aspect of its pharmacology directly relevant to the possible pathogenic mechanisms.

Despite the importance of the 5-HT hypothesis for explaining the etiology of fenfluramineassociated VHD, the effects of fenfluramine and related agents on plasma 5-HT have not been well studied. Research investigations conducted in the 1990s are not consistent with the 5-HT hypothesis, since they show that acute fenfluramine does not increase plasma 5-HT in rats 42 , and chronic fenfluramine lowers blood 5-HT in humans (see 43 and references therein). It is noteworthy that most studies report baseline plasma 5-HT levels at least 10-times higher than actual values (i.e., $\sim 1 \mathrm{nM}$ ), perhaps reflecting the difficulties in preparing plasma without platelet activation and subsequent 5-HT release.

Given the uncertainties regarding the validity of the 5-HT hypothesis, we developed a microdialysis method to measure plasma levels of 5-HT in whole blood samples from conscious catheterized rats. Our method involves careful blood handling to minimize the chance of platelet activation or lysis that would trigger 5-HT release 17 . Using this method, we showed that baseline dialysate levels of 5-HT in rat blood are approximately $0.20 \mathrm{nM}$, or about $1 \mathrm{nM}$ when corrected for probe recovery. The data in Fig. 3 demonstrate that acute i.v. administration of fenfluramine, or other SERT substrates such as 3,4-

methylenedioxymethamphetamine (MDMA) and methamphetamine, evokes dose-dependent increases in plasma 5-HT ranging from 4-fold to more than 20-fold above baseline. In contrast, amphetamine and phentermine, which have low potency as SERT substrates, produce much 
smaller increases in plasma 5-HT. Acute administration of the SERT uptake blocker fluoxetine produces modest but significant increases in plasma 5-HT. When fenfluramine and other SERT substrates are added directly to blood samples in vitro, dose-dependent increases in plasma 5HT are observed. Importantly, the potency of drugs to elevate plasma 5-HT correlates significantly with their ability to evoke $\left[{ }^{3} \mathrm{H}\right] 5-\mathrm{HT}$ release from rat brain synaptosomes, implicating a critical role for SERT. Taken together, our microdialysis findings suggest that fenfluramine and other SERT substrates are able to increase plasma 5 -HT by interacting with SERT proteins, most likely those expressed on platelets. Our data are consistent with older literature demonstrating that fenfluramine releases 5-HT from platelets in vitro 44,45 and functions as a substrate for platelet SERT proteins ${ }^{46}$. In contrast, our findings do not agree with those of Johnson et al. ${ }^{47}$ who reported that (+)-fenfluramine does not release $\left[{ }^{14} \mathrm{C}\right] 5-\mathrm{HT}$ from human platelets in vitro. A possible explanation for the differences between our findings and those of Johnson et al. is that we measured the release of endogenous 5-HT in whole blood samples, rather than the release of preloaded $\left[{ }^{14} \mathrm{C}\right] 5-\mathrm{HT}$ from isolated platelets.

The next logical step in these studies was to determine the effect of chronic fenfluramine on plasma $5-\mathrm{HT}{ }^{48}$, and we examined the effects of chronic fluoxetine for comparative purposes. As depicted in Fig. 4, chronic administration of fenfluramine via 14 days of osmotic minipump infusion significantly increases baseline plasma 5 -HT levels 2-fold and 4-fold after $3 \mathrm{mg} / \mathrm{kg} /$ day and $10 \mathrm{mg} / \mathrm{kg} /$ day, respectively. Interestingly, exposure to chronic fenfluramine significantly and dose-dependently reduces the ability of acute i.v. fenfluramine $(1 \mathrm{mg} / \mathrm{kg})$ to increase plasma 5-HT. Acute administration of fenfluramine elevates extracellular 5-HT by 20-fold in saline-pretreated rats, as compared to 6-fold and 4-fold following chronic administration of 3 and $10 \mathrm{mg} / \mathrm{kg} / \mathrm{d}( \pm$ )-fenfluramine. By comparison, chronic administration of fluoxetine via 14 days of osmotic minipump infusion does not change baseline plasma 5HT levels. However, chronic fluoxetine significantly and dose-dependently reduces the effects of acute fenfluramine on plasma 5-HT. An acute challenge dose of i.v. fenfluramine $(1 \mathrm{mg} / \mathrm{kg})$ elevates extracellular 5-HT by 18 -fold in the vehicle condition, as compared to 4 -fold and 2fold following the chronic administration of 3 and $10 \mathrm{mg} / \mathrm{kg} / \mathrm{d}$ of fluoxetine. These data reveal that chronic exposure to fenfluramine or fluoxetine markedly diminishes the ability of acute fenfluramine to evoke increases in plasma 5-HT.

Chronic administration of fenfluramine and fluoxetine significantly alters whole blood levels of 5-HT. As shown in Figure 5, chronic fenfluramine reduces whole blood 5-HT by about 40\% compared with saline control when measured 7 days after minipump implantation. Similar reductions are observed at day 13 . The fenfluramine-induced reduction in blood 5-HT is not dose-dependent, indicating that the ability of fenfluramine to deplete platelet 5-HT has already reached a maximal effect at the $3 \mathrm{mg} / \mathrm{kg} / \mathrm{d}$ dose. Chronic fluoxetine dose-dependently and significantly reduces whole blood $5-\mathrm{HT}$ by $\sim 35 \%$ ( $3 \mathrm{mg} / \mathrm{kg} / \mathrm{day}$ ) and $\sim 75 \%$ (10 mg/kg/day) compared with saline control when measured 7 days after minipump implantation, and this reduction is sustained up to 13 days. The whole blood data indicate that fenfluramine and fluoxetine deplete platelet 5-HT, and this effect may help to explain the reduction in fenfluramine-induced 5-HT release after these chronic drug treatments.

We also measured circulating levels of fenfluramine, fluoxetine and their respective metabolites after 13 days of chronic drug administration. The blood concentration of fenfluramine is increased significantly from 55 to $212 \mathrm{ng} / \mathrm{ml}$ when the dose of infused drug is increased from 3 to $10 \mathrm{mg} / \mathrm{kg} / \mathrm{day}$. The blood level of norfenfluramine also rises from 19 to $115 \mathrm{ng} / \mathrm{ml}$ in the same rats. The blood levels of fenfluramine and norfenfluramine measured in rats receiving $3 \mathrm{mg} / \mathrm{kg} / \mathrm{day}$ are similar to those reported in humans taking $60 \mathrm{mg}$ fenfluramine/day, namely $62.9 \mathrm{ng} / \mathrm{ml}$ fenfluramine and $20.7 \mathrm{ng} / \mathrm{ml}$ norfenfluramine ${ }^{43}$. After 13 days of chronic administration of fluoxetine, the fluoxetine blood concentrations are 11 and $113 \mathrm{ng} / \mathrm{ml}$ after the 3 and $10 \mathrm{mg} / \mathrm{kg} /$ day doses, respectively. The blood levels of norfluoxetine 
are 74 and $795 \mathrm{ng} / \mathrm{ml}$ in the same rats. The blood levels of fluoxetine and norfluoxetine measured in rats receiving $10 \mathrm{mg} / \mathrm{kg} / \mathrm{day}$ are similar to those reported in humans taking $20 \mathrm{mg}$ fluoxetine/day ${ }^{49}$. Our pharmacokinetic data demonstrate that osmotic minipump delivery of fenfluramine and fluoxetine to rats can produce drug and metabolite levels that are similar to those observed in patients taking prescribed doses of these medications.

It is now well accepted that large elevations in blood 5-HT produced by experimental methods in rodents, or pathological conditions in humans, can cause VHD with characteristic plaquelike encasement of valve leaflets $50-52$. By contrast, chronic administration of fenfluramine does not uniformly produce VHD in rodents, and no reproducible animal model has been established in this regard 53,54 . In one study, Gustafsson et al. (2005) administered chronic daily injections of exogenous 5-HT to induce VHD in rats. In their study, "free" 5-HT was measured using in vivo microdialysis in femoral muscle, rather than in a peripheral vein. Free 5-HT levels ranged from $580 \mathrm{nM}$ to $974 \mathrm{nM}$ when corrected for $31 \%$ probe recovery. These values are at least 100-fold higher than the low nM levels of 5-HT observed after chronic fenfluramine treatment in our study ${ }^{48}$. Gustafsson et al. (2005) also reported that chronic administration of 5-HT increased whole blood levels of 5-HT from 6,986 nM to 21,236 nM. In our study (Fig. 5), as expected on the basis of previous work (see 43 and references therein), chronic fenfluramine decreased whole blood 5 -HT by $40 \%$. These considerations support the hypothesis that chronic fenfluramine does not increase 5-HT concentrations in plasma or blood to a level reported to cause VHD in the rat. It is important to note, however, that the threshold dose of exogenous 5-HT required to produce VHD has not been determined, and this issue warrants further experimentation.

Several studies report that carcinoid syndrome causes marked increases in platelet 5-HT. Kema et al 55 reported that patients with carcinoid tumors had median platelet 5-HT levels of 31.45 $\mathrm{nmol} / 10^{9}$ platelets as compared to 4.4 in normal controls. In a later study, the same group showed that carcinoid patients had median platelet 5-HT levels of $23.8 \mathrm{nmol} / 10^{9}$ platelets as compared to 3.4 in normal controls 56 . A similar 8.6-fold increase in platelet 5-HT was reported by others 57 . Robiolio et al. ${ }^{50}$ reported that carcinoid patients with VHD have higher serum and platelet 5-HT levels than carcinoid patients without VHD. The serum and platelet 5-HT levels in carcinoid patients with VHD were elevated 11.5-fold and 6.6-fold, respectively, as compared to normal controls. Since the increased levels of 5-HT in blood and platelets observed in rat models 51 and in carcinoid patients is driven by indirect infusion of 5-HT into the blood stream, it is reasonable to conclude that such elevations in blood and platelet 5-HT will also result in large increases ( $>20$-fold) in plasma 5 -HT. In our rat study, chronic fenfluramine at clinically-relevant doses decreased blood 5-HT levels, and increased plasma 5-HT only 2-fold to 4-fold above baseline. Again these data dispute the notion that chronic fenfluramine increases plasma or blood 5-HT to a level sufficient to cause VHD in humans. Our results are similar to those observed in rats chronically exposed to hypoxic conditions 58 . Of course, we cannot exclude the possibility that small increases in plasma 5-HT produced by chronic fenfluramine could be enough to stimulate mitogenic responses in susceptible individuals and increase the risk of developing VHD. However, this scenario seems unlikely since treatment with lithium 59 or MAO inhibitors 60 , which are nor known to increase the risk of VHD, produces comparable increments in plasma 5-HT.

When viewed collectively, the available evidence is not compatible with the 5-HT hypothesis of fenfluramine-associated VHD 41,61. Although the 5-HT hypothesis may have been tenable as an explanation of fenfluramine-associated VHD at one point, recent studies implicate 5$\mathrm{HT}_{2 \mathrm{~B}}$ receptors, rather than plasma 5-HT per se, as the culprit in the pathogenesis of this disease 39 . As will be described in the next section, medications that are known to induce VHD such as fenfluramine, methysergide, ergotamine, pergolide and cabergoline share a common mechanism - namely, these drugs or their major metabolites are potent and efficacious 5- 
$\mathrm{HT}_{2 \mathrm{~B}}$ agonists. 5- $\mathrm{HT}_{2 \mathrm{~B}}$ receptors are richly expressed in heart valve cells. When stimulated, these cells undergo mitogenesis that leads to excessive growth culminating in valvulopathy (for review, see ${ }^{18}$ ).

\section{Serotonin $5-\mathrm{HT}_{2 B}$ receptors and Valvular Heart Disease}

Based on historical data, and our microdialysis findings reviewed above, we surmised that elevations in plasma 5-HT are not involved in the etiology of fenfluramine-associated VHD. Therefore, in a separate set of experiments, we investigated whether stereoisomers of fenfluramine or norfenfluramine might directly activate specific 5-HT receptor subtypes mediating mitogenic effects ${ }^{39}$. A number of additional test drugs were included in these experiments as positive and negative controls. "Positive controls" were ergot alkaloids known to increase the risk of VHD, such as methysergide, its active metabolite methylergonovine, and ergotamine 62-64. "Negative controls" were drugs that interact with monoamine transporters but were not known to cause VHD. These drugs included phentermine, fluoxetine and its metabolite norfluoxetine. Echocardiographic studies in humans support the assertion that fluoxetine (and other SSRIs) ${ }^{65}$, phentermine 66 and sibutramine (a NE/5-HT uptake inhibitor) ${ }^{67}$ do not cause VHD. We also tested the antidepressant trazodone and its active metabolite, m-chlorophenylpiperazine (mCPP), as negative controls 68,69 . mCPP has agonist activity at a wide range of 5-HT receptor subtypes 2,70 and is capable of releasing neuronal 5 -HT via a transporter-mediated mechanism similar to fenfluramines 71,72 .

Our working hypothesis was that fenfluramines, norfenfluramines and positive control drugs would share the ability to activate a mitogenic 5-HT receptor subtype expressed in heart valves, while the negative control drugs would not. An initial receptorome screen led to a detailed evaluation of the binding of these drugs to the $5-\mathrm{HT}_{2}$ family of receptors 39 . Table 2 reports binding data, and Table 3 reports the functional effects of these compounds at cloned human $5-\mathrm{HT}_{2 \mathrm{~A}}, 5-\mathrm{HT}_{2 \mathrm{~B}}$ and $5-\mathrm{HT}_{2 \mathrm{C}}$ receptors. Interestingly, fenfluramines have low affinity for all $5-\mathrm{HT}_{2}$ receptor subtypes. By contrast, we found that norfenfluramines display high affinity and efficacy at the $5-\mathrm{HT}_{2 \mathrm{~B}}$ receptor subtype $\left(\mathrm{K}_{\mathrm{I}}=10-50 \mathrm{nM}\right)$, consistent with the findings of others 38,73 . Methysergide acts as a partial agonist at the $5-\mathrm{HT}_{2 \mathrm{~B}}$ receptor, while the metabolite methylergonovine has even greater affinity and efficacy. Ergotamine is a potent partial agonist at the 5- $\mathrm{HT}_{2 \mathrm{~B}}$ receptor. Among the negative control drugs tested, only mCPP exhibits agonist activity at the 5- $\mathrm{HT}_{2 \mathrm{~B}}$ site. It is noteworthy that trazodone binds to the 5$\mathrm{HT}_{2 \mathrm{~B}}$ receptor with moderate affinity, but functions as an antagonist. Thus, when trazodone is metabolized to $\mathrm{mCPP}$ in vivo 68,69 the $5-\mathrm{HT}_{2 \mathrm{~B}}$ actions of mCPP are probably blocked by antagonist actions of the parent compound. Findings summarized by Setola et al. ${ }^{74}$ emphasize that many valvulopathic agents are actually "pro-drugs" which are converted to bioactive metabolites with 5- $\mathrm{HT}_{2 \mathrm{~B}}$ activity. Specific examples of this pro-drug phenomenon are illustrated by 3,4-methylenedioxymethamphetamine (MDMA) and methysergide- these parent drugs are $N$-demethylated to form metabolites which are potent efficacious $5-\mathrm{HT}_{2 \mathrm{~B}}$ agonists.

Our results with the various positive control drugs strongly implicate the $5-\mathrm{HT}_{2 \mathrm{~B}}$ receptor as a major culprit in the development of drug-induced VHD, and accumulating data support this hypothesis $18,38,73,75.5-\mathrm{HT}_{2 \mathrm{~B}}$ receptors are abundantly expressed on aortic and mitral valves ${ }^{38}$, and these receptors are known to stimulate mitogenisis 76,77 . Further evidence for the role of 5- $\mathrm{HT}_{2 \mathrm{~B}}$ receptors in drug-induced VHD is based on the effects of ergot medications such as carbergoline and pergolide. Both of these medications increase the risk of VHD in human patients and are also potent $5-\mathrm{HT}_{2 \mathrm{~B}}$ receptor agonists (for review see: ${ }^{18}$ ). In contrast, the $5-\mathrm{HT}_{2 \mathrm{~B}}$ receptor antagonist lisuride does not increase the risk for VHD ${ }^{18}, 78$. Setola and coworkers 75 showed that the illicit amphetamine analog MDMA and its $N$-demethylated metabolite, 3,4-methylenedioxyamphetamine (MDA), are 5- $\mathrm{HT}_{2 \mathrm{~B}}$ receptor agonists. These drugs stimulate prolonged mitogenic responses in human valvular interstitial cells via 
activation of $5-\mathrm{HT}_{2 \mathrm{~B}}$ receptors ${ }^{74}$, probably via phosphorylation of extracellular kinases (ERK) and Src kinase. ${ }^{18}$. As predicted by this study, a recent clinical report found that heavy MDMA users display a significantly higher incidence of valvular regurgitation when compared to control subjects ${ }^{79}$. More clinical investigations are needed to clearly establish the link between illicit MDMA use and the risk for developing VHD

\section{Conclusions}

$( \pm)$-Fenfluramine is a drug with complex pharmacological actions. Stereoisomers of $( \pm)$ fenfluramine are rapidly metabolized to form (+)- and (-)-norfenfluramine. All of these isomers are potent SERT substrates that release endogenous 5-HT from neurons. Additionally, norfenfluramines displays a number of other effects including substrate activity at NET to release $\mathrm{NE}$, and direct agonist activation of $5-\mathrm{HT}_{2 \mathrm{~B}}$ and $5-\mathrm{HT}_{2 \mathrm{C}}$ receptor subtypes. Acute administration of fenfluramine produces transient increases plasma 5-HT, but chronic administration of the drug causes only modest elevations in baseline plasma 5-HT. Substantial evidence now confirms that fenfluramine-induced increases in plasma 5-HT are not sufficient produce VHD. At the present time, the most likely explanation for fenfluramine-associated valvulopathy is activation of $5-\mathrm{HT}_{2 \mathrm{~B}}$ receptors by norfenfluramine. In agreement with this hypothesis, all medications that are known to produce VHD are 5- $\mathrm{HT}_{2 \mathrm{~B}}$ receptor agonists. It seems feasible that modest elevations in plasma 5 -HT produced by fenfluramine administration could play a synergistic role with direct actions of norfenfluramine on 5- $\mathrm{HT}_{2 \mathrm{~B}}$ receptors. However, a significant contribution of plasma 5-HT is unlikely because plasma concentrations of fenfluramine and norfenfluramine (i.e., $\sim 100 \mathrm{nM}$ ) far exceed plasma concentrations of 5HT. In addition, 5- $\mathrm{HT}_{2 \mathrm{~B}}$ agonists which do not elevate plasma 5-HT cause VHD, while medications which produce small increases in plasma 5-HT do not. Taken together, the findings support our opinion and those of our collaborators 18 that investigational medications and their metabolites should be devoid of agonist activity at $5-\mathrm{HT}_{2 \mathrm{~B}}$ receptors when administered at clinical doses. Similarly, physicians should exercise caution when prescribing existing medications that are known to be $5-\mathrm{HT}_{2 \mathrm{~B}}$ receptor agonists.

\section{Expert Opinion}

The widespread use of fenfluramines in the 1990s ultimately led to the recognition of VHD as an unexpected adverse effect. A role for serotonergic mechanisms in the etiology of fenfluramine-associated VHD was suspected early on. Indeed, some investigators suggested that: "caution should be urged in the long-term use of other agents that act on serotonergic mechanisms, albeit by different pathways" 80 . Such opinions introduced doubt about the safety of a many serotonergic medications, including antidepressants that block the uptake of 5-HT. Several possible pathogenic mechanisms were proposed to explain fenfluramine-associated VHD. These mechanisms included fenfluramine-induced increases in plasma 5-HT ${ }^{41}$ and synergistic interactions with phentermine to block monoamine oxidase type-A ${ }^{81}$. Several lines of evidence reviewed here and elsewhere strongly argue against these hypotheses 13, 48, 82 . It has been established that all medications associated with cardiac valvulopathy share the common ability to activate $5-\mathrm{HT}_{2 \mathrm{~B}}$ receptors, thus providing the simplest mechanistic explanation for fenfluramine-associated VHD 38,39 . Recently, several compounds including pergolide, cabergoline and MDMA were identified as 5- $\mathrm{HT}_{2 \mathrm{~B}}$ receptor agonists and predicted to be valvulopathic 74,75 . These predictions have been borne out by subsequent clinical investigations 18,79 . Viewed collectively, the data support our opinion and those of our collaborators 18 that new candidate medications and their metabolites should be designed to avoid agonist activity at the 5- $\mathrm{HT}_{2 \mathrm{~B}}$ receptor. Physicians should exercise caution in prescribing medications that are known to be 5- $\mathrm{HT}_{2 \mathrm{~B}}$ receptor agonists. Finally, the observation that MDMA may produce VHD deserves additional study, as this adverse effect may ultimately cause greater morbidity than the widely studied effects of MDMA on brain function 83,84 . 


\title{
Acknowledgments
}

\author{
Declaration of interests
}

This work was supported by the Intramural Research Program, National Institute on Drug Abuse National Institutes of Health, Department of Health and Human Services.

\section{References}

1. Weiger WA. Serotonergic modulation of behaviour: a phylogenetic overview. Biol Rev Camb Philos Soc 1997 Feb;72(1):61-95. [PubMed: 9116165]

2. Hoyer D, Hannon JP, Martin GR. Molecular, pharmacological and functional diversity of 5-HT receptors. Pharmacol Biochem Behav 2002 Apr;71(4):533-54. [PubMed: 11888546]

3. Nichols DE, Nichols CD. Serotonin receptors. Chem Rev 2008 May;108(5):1614-41. [PubMed: 18476671]

4. Connolly HM, Crary JL, McGoon MD, Hensrud DD, Edwards BS, Schaff HV. Valvular heart disease associated with fenfluramine-phentermine. NEnglJMed 1997;337(9):581-8.

5. Connolly HM, McGoon MD. Obesity drugs and the heart. Curr Probl Cardiol 1999;24:745-92. [PubMed: 10609092]

6. Sachdev M, Miller WC, Ryan T, Jollis JG. Effect of fenfluramine-derivative diet pills on cardiac valves: a meta-analysis of observational studies. Am Heart J 2002 Dec;144(6):1065-73. [PubMed: 12486432]

7. Loke YK, Derry S, Pritchard-Copley A. Appetite suppressants and valvular heart disease - a systematic review. BMC Clin Pharmacol 2002 Aug 23;2:6. [PubMed: 12194699]

8. Gardin JM, Weissman NJ, Leung C, Panza JA, Fernicola D, Davis KD, et al. Clinical and echocardiographic follow-up of patients previously treated with dexfenfluramine or phentermine/ fenfluramine. JAMA 2001;286:2011-4. [PubMed: 11667938]

9. Jick H, Vasilakis C, Weinrauch LA, Meier CR, Jick SS, Derby LE. A population-based study of appetite-suppressant drugs and the risk of cardiac-valve regurgitation [see comments]. NEnglJMed 1998;339:719-24.

10. Fleming RM, Boyd LB. The longitudinal effects of fenfluramine-phentermine use. Angiology 2007 Jun-Jul;58(3):353-9. [PubMed: 17626991]

11. Weissman NJ. Appetite suppressants and valvular heart disease. AmJMedSci 2001;321:285-91.

12. Dahl CF, Allen MR, Urie PM, Hopkins PN. Valvular regurgitation and surgery associated with fenfluramine use: an analysis of 5743 individuals. BMC medicine 2008 Nov 6;6(1):34. [PubMed: 18990200]

13. Baumann MH, Ayestas MA, Dersch CM, Brockington A, Rice KC, Rothman RB. Effects of phentermine and fenfluramine on extracellular dopamine and serotonin in rat nucleus accumbens: therapeutic implications. Synapse 2000;36:102-13. [PubMed: 10767057]

14. Rothman RB, Clark RD, Partilla JS, Baumann MH. (+)-fenfluramine and its major metabolite, (+)norfenfluramine, are potent substrates for norepinephrine transporters. J Pharmacol Exp Ther 2003 Jun;305(3):1191-9. [PubMed: 12649307]

15. Nemecek GM, Coughlin SR, Handley DA, Moskowitz MA. Stimulation of aortic smooth muscle cell mitogenesis by serotonin. Proc Natl Acad Sci U S A 1986;83:674-8. [PubMed: 3456163]

16. Seuwen K, Magnaldo I, Pouyssegur J. Serotonin stimulates DNA synthesis in fibroblasts acting through 5-HT1B receptors coupled to a Gi-protein. Nature 1988;335:254-6. [PubMed: 3045568]

17. Zolkowska D, Rothman RB, Baumann MH. Amphetamine analogs increase plasma serotonin: implications for cardiac and pulmonary disease. J Pharmacol Exp Ther 2006 Aug;318(2):604-10. [PubMed: 16644904]

18. Roth BL. Drugs and valvular heart disease. N Engl J Med 2007 Jan 4;356(1):6-9. [PubMed: 17202450]

19. Pinder RM, Brogden RN, Sawyer PR, Speight TM, Avery GS. Fenfluramine: a review of its pharmacological properties and therapeutic efficacy in obesity. Drugs 1975;10:241-323. [PubMed: $765100]$ 
20. Rothman RB, Baumann M. Therapeutic and adverse actions of serotonin transporter substrates. Pharmacol Ther 2002 Jul;95(1):73-88. [PubMed: 12163129]

21. Rudnick G, Clark J. From synapse to vesicle: the reuptake and storage of biogenic amine neurotransmitters [Review]. Biochim Biophys Acta 1993;1144:249-63. [PubMed: 8104483]

22. Garattini S, Mennini T, Bendotti C, Invernizzi R, Samanin R. Neurochemical mechanism of action of drugs which modify feeding via the serotoninergic system. Appetite 1986;7 (Suppl):15-38. [PubMed: 2427023]

23. Gundlah C, Martin KF, Heal DJ, Auerbach SB. In vivo criteria to differentiate monoamine reuptake inhibitors from releasing agents: sibutramine is a reuptake inhibitor. J Pharmacol Exp Ther 1997;283:581-91. [PubMed: 9353373]

24. Tao R, Fray A, Aspley S, Brammer R, Heal D, Auerbach S. Effects on serotonin in rat hypothalamus of D-fenfluramine, aminorex, phentermine and fluoxetine. Eur J Pharmacol 2002 Jun 7;445(1-2): 69-81. [PubMed: 12065196]

25. Caccia S, Conforti I, Duchier J, Garattini S. Pharmacokinetics of fenfluramine and norfenfluramine in volunteers given D- and DL-fenfluramine for 15 days. Eur J Clin Pharmacol 1985;29:221-4. [PubMed: 4076322]

26. Marchant NC, Breen MA, Wallace D, Bass S, Taylor AR, Ings RM, et al. Comparative biodisposition and metabolism of 14C-(+/-)-fenfluramine in mouse, rat, dog and man. Xenobiotica 1992 Nov;22 (11):1251-66. [PubMed: 1492418]

27. Rothman RB, Partilla JS, Baumann MH, Dersch CM, Carroll FI, Rice KC. Neurochemical neutralization of methamphetamine with high affinity non-selective inhibitors of biogenic amine transporters: a pharmacological strategy for treating stimulant abuse. Synapse 2000;35:222-7. [PubMed: 10657029]

28. Rothman RB, Baumann MH, Dersch CM, Romero DV, Rice KC, Carroll FI, et al. Amphetaminetype central nervous system stimulants release norepinephrine more potently than they release dopamine and serotonin. Synapse 2001;39:32-41. [PubMed: 11071707]

29. Pettersson E. Studies of four novel diphenylbutylpiperazinepyridyl derivatives on release and inhibition of reuptake of dopamine, serotonin and noradrenaline by rat brain in vitro. EurJPharmacol 1995;282:131-5.

30. Cozzi NV, Frescas S, Marona-Lewicka D, Huang X, Nichols DE. Indan analogs of fenfluramine and norfenfluramine have reduced neurotoxic potential. Pharmacol Biochem Behav 1998;59:709-15. [PubMed: 9512076]

31. Rothman RB, Ayestas MA, Dersch CM, Baumann MH. Aminorex, fenfluramine, and chlorphentermine are serotonin transporter substrates: implications for primary pulmonary hypertension. Circulation 1999;100:869-75. [PubMed: 10458725]

32. Garattini S. Biological actions of drugs affecting serotonin and eating. ObesRes 1995;3 (Suppl 4): 463S-70S.

33. Vickers SP, Clifton PG, Dourish CT, Tecott LH. Reduced satiating effect of d-fenfluramine in serotonin 5-HT(2C) receptor mutant mice. Psychopharmacology (Berl) 1999;143:309-14. [PubMed: 10353435]

34. Vickers SP, Benwell KR, Porter RH, Bickerdike MJ, Kennett GA, Dourish CT. Comparative effects of continuous infusion of mCPP, Ro 60-0175 and d-fenfluramine on food intake, water intake, body weight and locomotor activity in rats [In Process Citation]. Br J Pharmacol 2000 Jul;130(6):130514. [PubMed: 10903970][MEDLINE record in process] 2000;130:1305-14 [MEDLINE.

35. Silverstone T. Appetite suppressants. A review Drugs 1992;43:820-36.

36. Tecott LH, Abdallah L. Mouse genetic approaches to feeding regulation: serotonin 5-HT2C receptor mutant mice. CNS spectrums 2003 Aug;8(8):584-8. [PubMed: 12907921]

37. Xu Y, Jones JE, Kohno D, Williams KW, Lee CE, Choi MJ, et al. 5-HT2CRs expressed by proopiomelanocortin neurons regulate energy homeostasis. Neuron 2008 Nov 26;60(4):582-9. [PubMed: 19038216]

38. Fitzgerald LW, Burn TC, Brown BS, Patterson JP, Corjay MH, Valentine PA, et al. Possible role of valvular serotonin 5- $\mathrm{HT}_{2 \mathrm{~B}}$ receptors in the cardiopathy associated with fenfluramine. Mol Pharmacol 2000;57:75-81. [PubMed: 10617681] 
39. Rothman RB, Baumann MH, Savage JE, Rauser L, McBride A, Hufisein S, et al. Evidence for possible involvement of 5- $\mathrm{HT}_{2 \mathrm{~B}}$ receptors in the cardiac valvulopathy associated with fenfluramine and other serotonergic medications. Circulation 2000;102:2836-41. [PubMed: 11104741]

40. Launay JM, Herve P, Peoc'h K, Tournois C, Callebert J, Nebigil CG, et al. Function of the serotonin 5-hydroxytryptamine 2B receptor in pulmonary hypertension. Nat Med 2002 Oct;8(10):1129-35. [PubMed: 12244304]

41. Fishman AP. Aminorex to fen/phen: an epidemic foretold. Circulation 1999;99:156-61. [PubMed: 9884392]

42. Martin F, Artigas F. Simultaneous effects of p-chloroamphetamine, d-fenfluramine, and reserpine on free and stored 5-hydroxytryptamine in brain and blood. JNeurochem 1992;59:1138-44. [PubMed: 1379630]

43. Rothman RB, Redmon JB, Raatz SK, Kwong CA, Swanson JE, Bantle JP. Chronic treatment with the phentermine combined with fenfluramine lowers plasma serotonin. AmJCardiol 2000;85:913-5.

44. Buczko W, De Gaetano G, Garattini S. Effect of some anorectic agents on the uptake and release of 5-hydroxytryptamine by blood platelets of rats. J Pharm Pharmacol 1975;27:366-8. [PubMed: 239141]

45. Picotti GB, Carruba MO, Zambotti F, Mantegazza P. Effects of mazindol and d-fenfluramine of 5hydroxytryptamine uptake, storage and metabolism in blood platelets. Eur J Pharmacol 1977 Apr 7;42(3):217-24. [PubMed: 856607]

46. Schuldiner S, Steiner-Mordoch S, Yelin R, Wall SC, Rudnick G. Amphetamine derivatives interact with both plasma membrane and secretory vesicle biogenic amine transporters. Molecular Pharmacology 1993;44:1227-31. [PubMed: 7903417]

47. Johnson GJ, Leis LA, Dunlop PC, Weir EK. The effect of the anorectic agent, d-fenfluramine, and its primary metabolite, d-norfenfluramine, on intact human platelet serotonin uptake and efflux. J Thromb Haemost 2003 Dec;1(12):2663-8. [PubMed: 14675103]

48. Zolkowska D, Baumann MH, Rothman RB. Chronic Fenfluramine Administration Increases Plasma Serotonin (5-HT) to Non-Toxic Levels. J Pharmacol Exp Ther 2007;324(2):791-7. [PubMed: 18032571]

49. Lundmark J, Reis M, Bengtsson F. Serum concentrations of fluoxetine in the clinical treatment setting. Ther Drug Monit 2001 Apr;23(2):139-47. [PubMed: 11294514]

50. Robiolio PA, Rigolin VH, Wilson JS, Harrison JK, Sanders LL, Bashore TM, et al. Carcinoid heart disease. Correlation of high serotonin levels with valvular abnormalities detected by cardiac catheterization and echocardiography. Circulation 1995;92:790-5. [PubMed: 7641358]

51. Gustafsson BI, Tommeras K, Nordrum I, Loennechen JP, Brunsvik A, Solligard E, et al. Long-term serotonin administration induces heart valve disease in rats. Circulation 2005 Mar 29;111(12):151722. [PubMed: 15781732]

52. Droogmans S, Franken PR, Garbar C, Weytjens C, Cosyns B, Lahoutte T, et al. In vivo model of drug-induced valvular heart disease in rats: pergolide-induced valvular heart disease demonstrated with echocardiography and correlation with pathology. Eur Heart J 2007 Sep;28(17):2156-62. [PubMed: 17636306]

53. Donnelly KB. Cardiac valvular pathology: comparative pathology and animal models of acquired cardiac valvular diseases. Toxicol Pathol 2008;36(2):204-17. [PubMed: 18474943]

54. Smith BM, Thomsen WJ, Grottick AJ. The potential use of selective 5-HT2C agonists in treating obesity. Expert Opin Investig Drugs 2006 Mar;15(3):257-66.

55. Kema IP, de Vries EG, Schellings AM, Postmus PE, Muskiet FA. Improved diagnosis of carcinoid tumors by measurement of platelet serotonin. Clin Chem 1992 Apr;38(4):534-40. [PubMed: 1373675]

56. Kema IP, Meijer WG, Meiborg G, Ooms B, Willemse PH, de Vries EG. Profiling of tryptophanrelated plasma indoles in patients with carcinoid tumors by automated, on-line, solid-phase extraction and HPLC with fluorescence detection. Clin Chem 2001 Oct;47(10):1811-20. [PubMed: 11568091]

57. Meijer WG, Kema IP, Volmer M, Willemse PH, de Vries EG. Discriminating capacity of indole markers in the diagnosis of carcinoid tumors. Clin Chem 2000 Oct;46(10):1588-96. [PubMed: 11017936] 
58. Eddahibi S, Raffestin B, Launay JM, Sitbon M, Adnot S. Effect of Dexfenfluramine Treatment in Rats Exposed to Acute and Chronic Hypoxia. Amer J Respir Crit Care Med 1998;157:1111-9. [PubMed: 9563727]

59. Artigas F, Sarrias MJ, Martinez E, Gelpi E, Alvarez E, Udina C. Increased plasma free serotonin but unchanged platelet serotonin in bipolar patients treated chronically with lithium. Psychopharmacology(Berl) 1989;99:328-32. [PubMed: 2480614]

60. Celada P, Dolera M, Alvarez E, Artigas F. Effects of acute and chronic treatment with fluvoxamine on extracellular and platelet serotonin in the blood of major depressive patients. Relationship to clinical improvement. J Affect Disord 1992 Aug;25(4):243-9. [PubMed: 1385505]

61. MacLean MR, Herve P, Eddahibi S, Adnot S. 5-hydroxytryptamine and the pulmonary circulation: receptors, transporters and relevance to pulmonary arterial hypertension. Br J Pharmacol 2000 Sep; 131(2):161-8. [PubMed: 10991906]

62. Bana DS, MacNeal PS, LeCompte PM, Shah Y, Graham JR. Cardiac murmurs and endocardial fibrosis associated with methysergide therapy. AmHeart J 1974;88:640-55.

63. Bredberg U, Eyjolfsdottir GS, Paalzow L, Tfelt-Hansen P, Tfelt-Hansen V. Pharmacokinetics of methysergide and its metabolite methylergometrine in man. Eur J Clin Pharmacol 1986;30:75-7. [PubMed: 3709634]

64. Hendrikx M, Van Dorpe J, Flameng W, Daenen W. Aortic and mitral valve disease induced by ergotamine therapy for migraine: a case report and review of the literature. Journal of Heart ValveDisease 1996;5:235-7.

65. Mast ST, Gersing KR, Anstrom KJ, Krishnan KR, Califf RM, Jollis JG. Association between selective serotonin-reuptake inhibitor therapy and heart valve regurgitation. AmJCardiol 2001;87:989-93.

66. Whigham LD, Dhurandhar NV, Rahko PS, Atkinson RL. Comparison of combinations of drugs for treatment of obesity: body weight and echocardiographic status. International journal of obesity (2005) 2007 May;31(5):850-7. [PubMed: 17146452]

67. Zannad F, Gille B, Grentzinger A, Bruntz JF, Hammadi M, Boivin JM, et al. Effects of sibutramine on ventricular dimensions and heart valves in obese patients during weight reduction. Am Heart $\mathrm{J}$ 2002 Sep;144(3):508-15. [PubMed: 12228789]

68. Ishida M, Otani K, Kaneko S, Ohkubo T, Osanai T, Yasui N, et al. Effects of various factors on steady state plasma concentrations of trazodone and its active metabolite $\mathrm{m}$-chlorophenylpiperazine. Int Clin Psychopharmacol 1995 Sep;10(3):143-6. [PubMed: 8675966]

69. Otani K, Mihara K, Yasui N, Ishida M, Kondo T, Tokinaga N, et al. Plasma concentrations of trazodone and $\mathrm{m}$-chlorophenylpiperazine at steady state can be predicted from those after an initial dose of trazodone. Prog Neuropsychopharmacol Biol Psychiatry 1997 Jan;21(1):239-44. [PubMed: 9075270]

70. Hoyer D, Clarke DE, Fozard JR, Hartig PR, Martin GR, Mylecharane EJ, et al. International Union of Pharmacology classification of receptors for 5-hydroxytryptamine (Serotonin). Pharmacol Rev 1994;46:157-203. [PubMed: 7938165]

71. Baumann MH, Rutter JJ, Auerbach SB. Intravenous administration of the serotonin agonist mchlorophenylpiperazine (mCPP) increases extracellular serotonin in the diencephalon of awake rats. Neuropharmacol 1993;32:1381-6.

72. Baumann MH, Ayestas MA, Dersch CM, Rothman RB. 1-(m-Chlorophenyl)piperazine (mCPP) Dissociates In Vivo Serotonin Release from Long-Term Serotonin Depletion in Rat Brain. Neuropsychopharmacology 2001;24:492-501. [PubMed: 11282249]

73. Porter RH, Benwell KR, Lamb H, Malcolm CS, Allen NH, Revell DF, et al. Functional characterization of agonists at recombinant human $5-\mathrm{HT}_{2 \mathrm{~A}}, 5-\mathrm{HT}_{2 \mathrm{~B}}$ and $5-\mathrm{HT}_{2} \mathrm{C}$ receptors in $\mathrm{CHO}-$ K1 cells. BrJPharmacol 1999;128:13-20.

74. Setola V, Hufeisen SJ, Grande-Allen KJ, Vesely I, Glennon RA, Blough B, et al. 3,4Methylenedioxymethamphetamine (MDMA, "Ecstasy") Induces Fenfluramine-Like Proliferative Actions on Human Cardiac Valvular Interstitial Cells in Vitro. Mol Pharmacol 2003 Jun;63(6):12239. [PubMed: 12761331]

75. Setola V, Roth BL. Screening the receptorome reveals molecular targets responsible for drug-induced side effects: focus on 'fen-phen'. Expert Opin Drug Metab Toxicol 2005;1(3):377-87. [PubMed: 16863450] 
76. Lopez-Ilasaca M. Signaling from G-protein-coupled receptors to mitogen-activated protein (MAP)kinase cascades. Biochem Pharmacol 1998;56:269-77. [PubMed: 9744561]

77. Hafizi S, Taylor PM, Chester AH, Allen SP, Yacoub MH. Mitogenic and secretory responses of human valve interstitial cells to vasoactive agents. J Heart Valve Dis 2000 May;9(3):454-8. [PubMed: 10888105]

78. Hofmann C, Penner U, Dorow R, Pertz HH, Jahnichen S, Horowski R, et al. Lisuride, a dopamine receptor agonist with 5-HT2B receptor antagonist properties: absence of cardiac valvulopathy adverse drug reaction reports supports the concept of a crucial role for 5-HT2B receptor agonism in cardiac valvular fibrosis. Clin Neuropharmacol 2006 Mar-Apr;29(2):80-6. [PubMed: 16614540]

79. Droogmans S, Cosyns B, D'Haenen H, Creeten E, Weytjens C, Franken PR, et al. Possible Association Between 3,4-Methylenedioxymethamphetamine Abuse and Valvular Heart Disease. The American Journal of Cardiology 2007;100(9):442-5. [PubMed: 17659925]

80. Devereux RB. Appetite suppressants and valvular heart disease. NEnglJMed 1998;339:765-7.

81. Maher TJ, Ulus IH, Wurtman RJ. Phentermine and other monoamine-oxidase inhibitors may increase plasma serotonin when given with fenfluramines. Lancet 1999;353:38. [PubMed: 10023954]

82. Alexander M, Rothman RB, Baumann MH, Endres CJ, Brasic JR, Wong DF. Noradrenergic and dopaminergic effects of (+)-amphetamine-like stimulants in the baboon Papio anubis. Synapse 2005 May;56(2):94-9. [PubMed: 15729739]

83. Karlsen SN, Spigset O, Slordal L. The dark side of ecstasy: neuropsychiatric symptoms after exposure to 3,4-methylenedioxymethamphetamine. Basic Clin Pharmacol Toxicol 2008 Jan;102(1):15-24. [PubMed: 18047478]

84. Gouzoulis-Mayfrank E, Daumann J. Neurotoxicity of methylenedioxyamphetamines (MDMA; ecstasy) in humans: how strong is the evidence for persistent brain damage? Addiction 2006 Mar; 101(3):348-61. [PubMed: 16499508] 


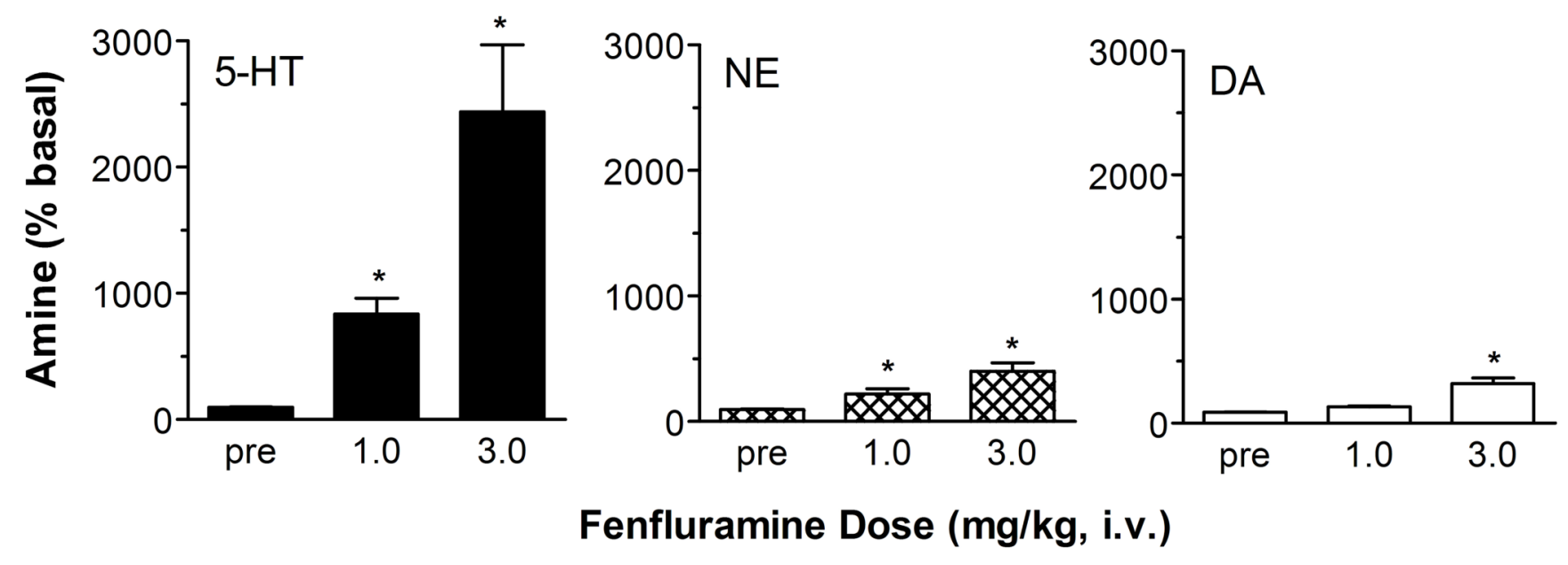

Figure 1.

Dose-response effects of (+)-fenfluramine on extracellular levels of 5-HT, NE and DA in rat frontal cortex. Rats undergoing in vivo microdialysis sampling received i.v. injections of 1.0 and $3.0 \mathrm{mg} / \mathrm{kg} \mathrm{(+)-fenfluramine} \mathrm{at} \mathrm{time} \mathrm{zero} \mathrm{and} 60 \mathrm{~min}$, respectively. Dialysate samples were collected at $20 \mathrm{~min}$ intervals and immediately assayed for 5-HT, NE and DA. Data are peak effects measured 20 min after drug injection, expressed as mean \pm SEM for $\mathrm{N}=6$ rats. 5-HT levels are normalized to $\%$ of preinjection baseline. $*=\mathrm{P}<0.05$ with respect to preinjection control. Figure modified from 14 . 

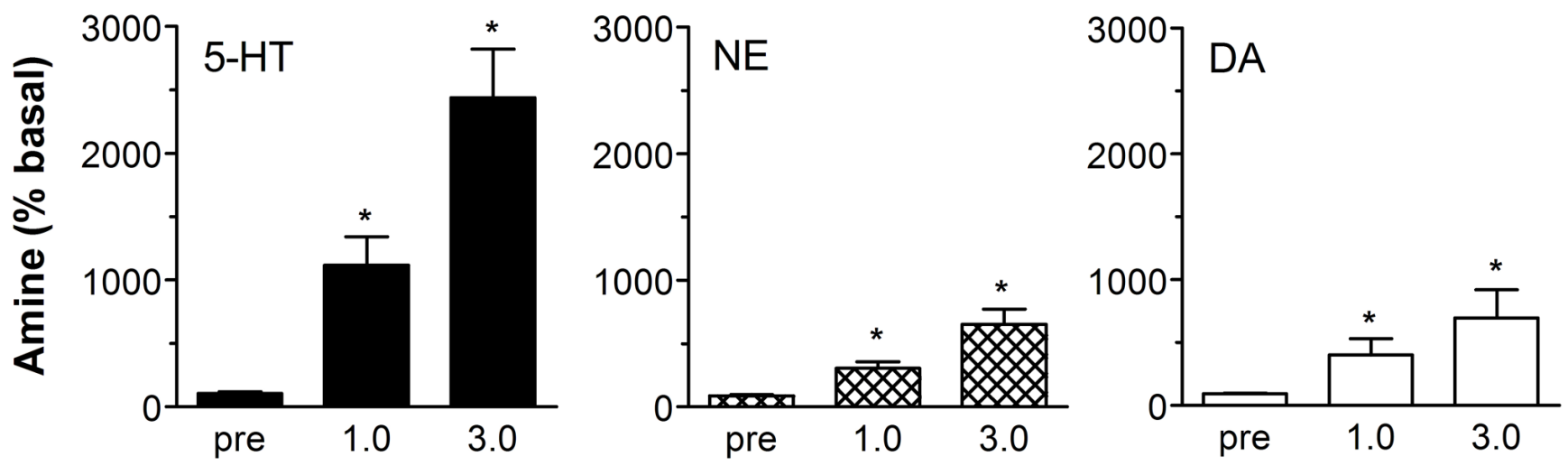

Norfenfluramine Dose (mg/kg, i.v.)

Figure 2.

Dose-response effects of (+)-norfenfluramine on extracellular levels of 5-HT, NE and DA in rat frontal cortex. Rats undergoing in vivo microdialysis sampling received i.v. injections of 1.0 and $3.0 \mathrm{mg} / \mathrm{kg}(+)$-norfenfluramine at time zero and $60 \mathrm{~min}$. Dialysate samples were collected at 20 min intervals and immediately assayed for 5-HT, NE and DA. Data are peak effects measured 20 min after drug injection, expressed as mean \pm SEM for $\mathrm{N}=6$ rats. 5-HT levels are normalized to $\%$ of preinjection baseline. $*=\mathrm{P}<0.05$ with respect to preinjection control. Figure modified from 14 . 

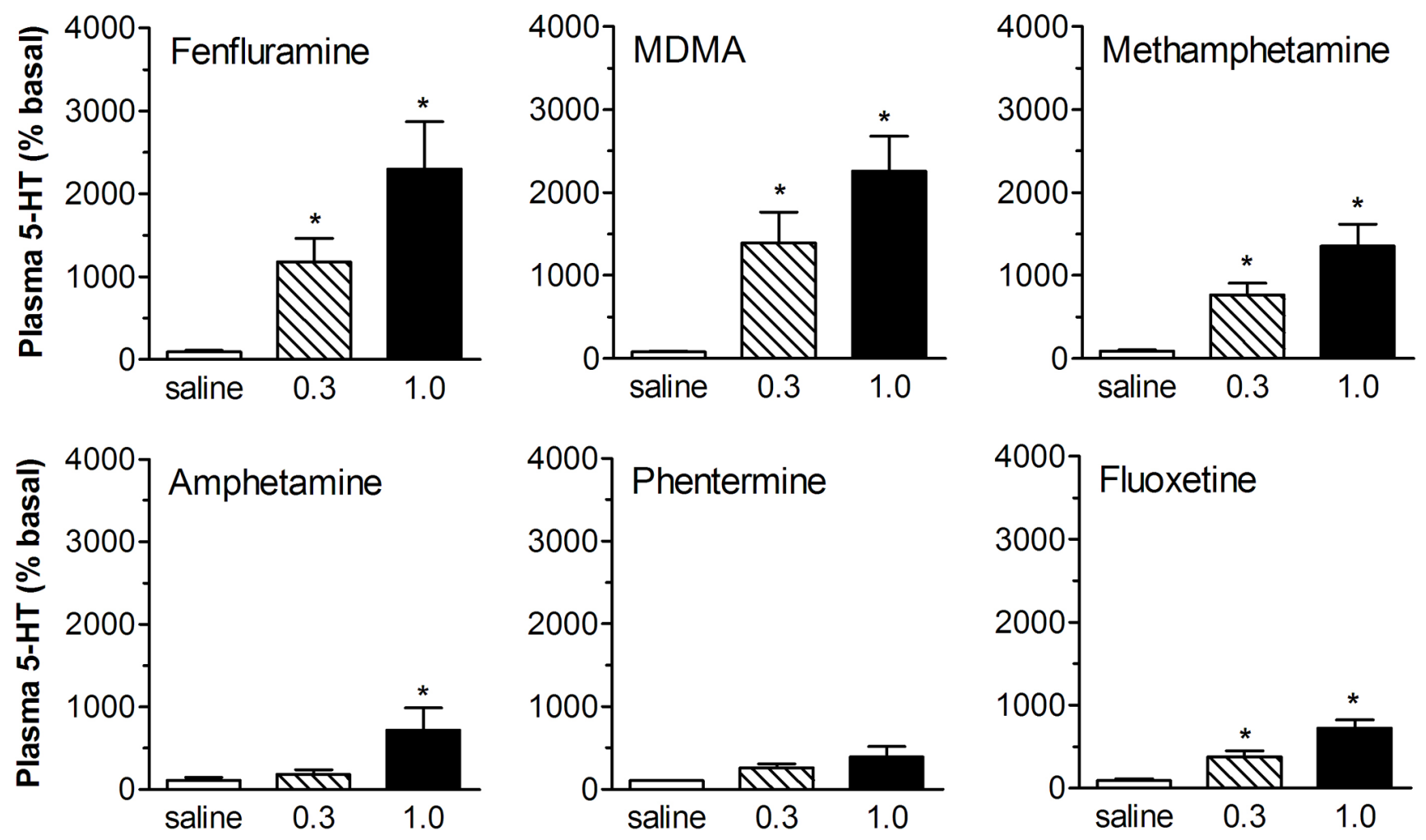

\section{Drug Dose (mg/kg, i.v.)}

Figure 3.

Effects of amphetamine analogs and fluoxetine on dialysate 5-HT levels measured in blood from conscious rats. Drug or saline vehicle was administered i.v. at time zero. Serial blood samples were withdrawn at 15 min intervals and dialyzed ex vivo. Dialysate samples were assayed for 5-HT. Data are peak effects measured in the first sample after drug injection, expressed as mean $\pm \mathrm{SEM}$ for $\mathrm{N}=6$ rats/group. 5-HT levels are normalized to $\%$ of preinjection baseline. $*=\mathrm{P}<0.05$ compared to saline controls. Figure modified from 17 . 

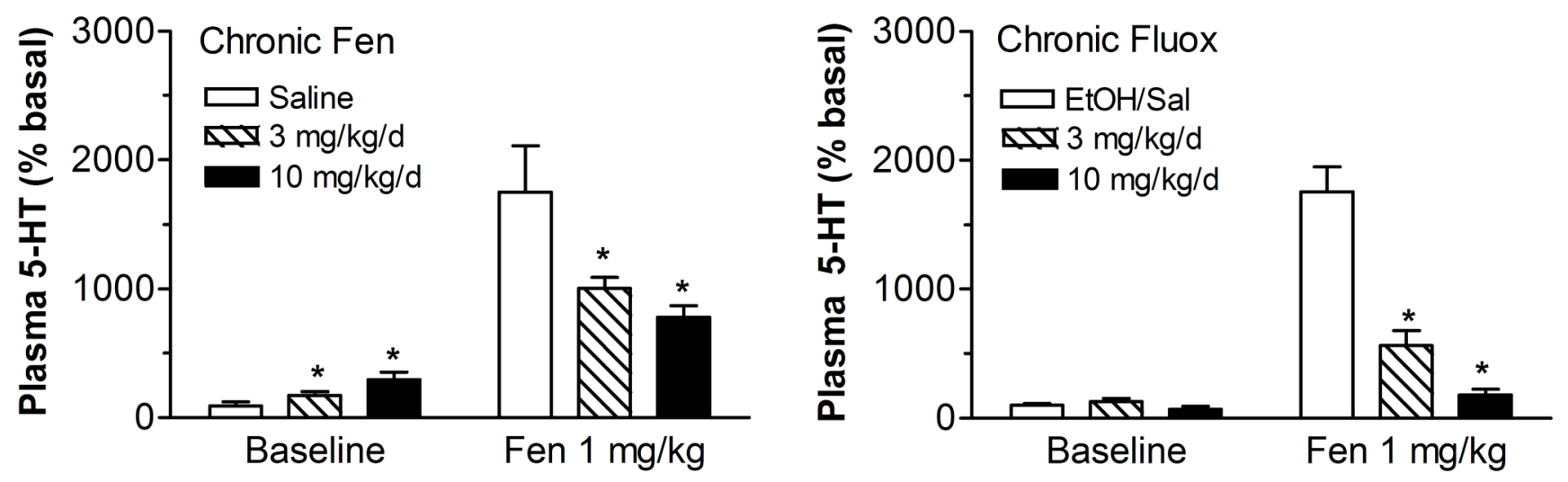

Figure 4.

Acute in vivo effects of $( \pm)$-fenfluramine on dialysate 5-HT levels measured in blood from conscious rats previously treated with chronic administration of $( \pm$ )-fenfluramine (fen) or fluoxetine (fluox). For chronic treatments, drugs were dissolved in saline (fen) or 50\% ethanol/ saline (fluox), and administered s.c. via osmotic minipumps for 2 weeks. On day 14, fenfluramine was dissolved in saline and administered i.v. at $0 \mathrm{~min}$. Serial blood samples were withdrawn at 15 min intervals and immediately dialyzed. Data are mean \pm SEM for $\mathrm{N}=9$ rats/ group. For Baseline effects, 5-HT levels are normalized to \% of vehicle control groups. For acute fenfluramine challenge effects, 5 -HT data are peak effects measured 15 min postinjection expressed $\%$ of preinjection baseline. ${ }^{*}=\mathrm{P}<0.05$ compared to saline-pretreated controls. Figure modified from 48 . 

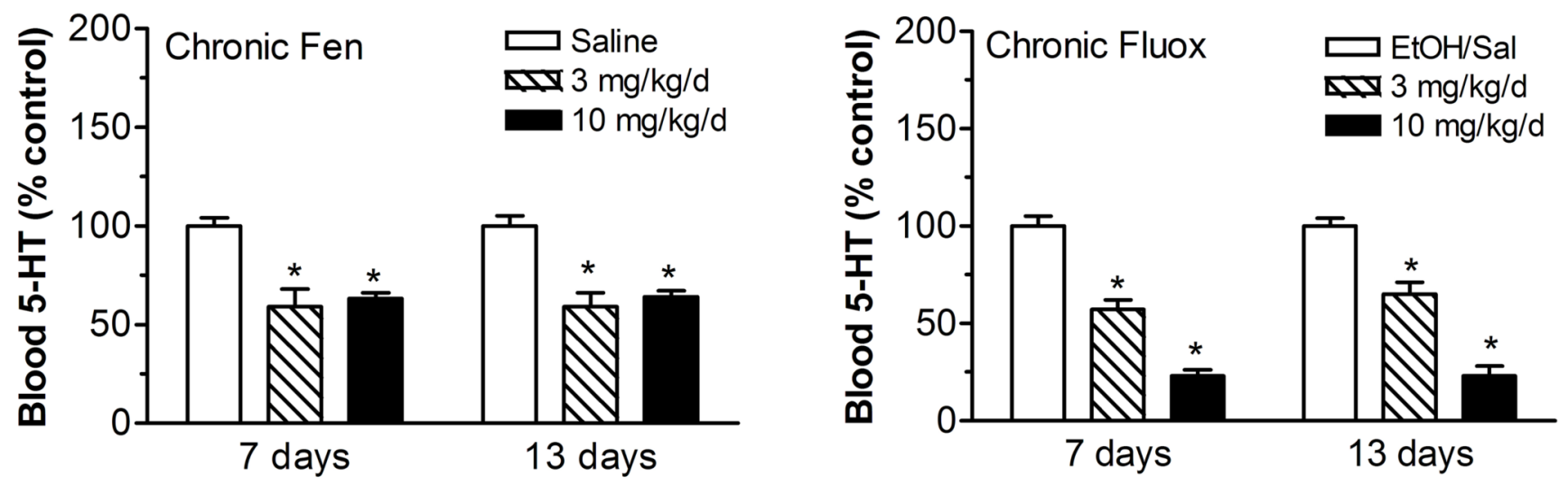

Figure 5.

Effects of chronic administration of ( \pm )-fenfluramine (fen) and fluoxetine (fluox) on whole blood 5-HT levels measured 7 and 13 days after minipump implantation. Drugs were dissolved in saline (fen) or 50\% ethanol/saline (fluox), and administered s.c. via osmotic minipumps for 2 weeks. Blood samples were withdrawn via indwelling jugular catheters and serum 5-HT was measured using double-antibody RIA methods. Data are mean \pm SEM for $\mathrm{N}=9$ rats/group expressed as $\%$ of vehicle control values. $*=\mathrm{P}<0.05$ compared to saline or ethanol/saline controls at corresponding time points. Figure modified from 48 . 
Table 1

$\mathrm{EC}_{50}$ Values of Test Drugs for Release of 5-HT, NE and DA.

\begin{tabular}{|c|c|c|c|}
\hline Drug & 5-HT Release (nM) & NE Release (nM) & DA Release (nM) \\
\hline$( \pm)$-fenfluramine ${ }^{l}$ & $79.3 \pm 11.5$ & $739 \pm 57$ & $>10,000$ \\
\hline$(+)$-fenfluramine ${ }^{l}$ & $51.7 \pm 6.1$ & $302 \pm 20$ & $>10,000$ \\
\hline$(-)$-fenfluramine & $147 \pm 19$ & $>10,000$ & $>10,000$ \\
\hline$( \pm)$-norfenfluramine & $104 \pm 5$ & $168 \pm 17$ & $1925 \pm 295$ \\
\hline$(+)$-norfenfluramine & $59.3 \pm 2.4$ & $72.7 \pm 5.4$ & $924 \pm 112$ \\
\hline$(-)$-norfenfluramine & $287 \pm 14$ & $474 \pm 40$ & $>10,000$ \\
\hline phentermine $^{l}$ & $3511 \pm 253$ & $39.4 \pm 6.6$ & $262 \pm 21$ \\
\hline$( \pm)-\mathrm{MDMA}^{l}$ & $56.6 \pm 2.1$ & $77.4 \pm 3.4$ & $376 \pm 16$ \\
\hline$(-)$-ephedrine ${ }^{l}$ & $2775 \pm 234$ & $72.4 \pm 10.2$ & $1350 \pm 124$ \\
\hline
\end{tabular}

Table is taken from ${ }^{14}$. Values are mean \pm SD for $n=3$ experiments.

${ }^{1}$ Data taken from ${ }^{28}$. 
Table 2

$\mathrm{Ki}$ Values of Test Drugs at $5-\mathrm{HT}_{2}$ Receptors.

\begin{tabular}{|l|l|l|l|}
\hline Drug & Human 5-HT & Human 5-HT & Human 5-HT \\
\hline$( \pm)$-Fenfluramine & $5216 \pm 423$ & $4134 \pm 1281$ & $3183 \pm 637$ \\
\hline$(+)$-Fenfluramine & $11107 \pm 2303$ & $5099 \pm 1173$ & $6245 \pm 874$ \\
\hline$(-)$-Fenfluramine & $5463 \pm 600$ & $5713 \pm 2285$ & $3415 \pm 922$ \\
\hline$( \pm)-$ Norfenfluramine & $2316 \pm 278$ & $52.1 \pm 21$ & $557 \pm 61$ \\
\hline$(+)-$ Norfenfluramine & $1516 \pm 150$ & $11.2 \pm 7.3$ & $324 \pm 12$ \\
\hline$(-)$-Norfenfluramine & $3841 \pm 614$ & $47.8 \pm 30.6$ & $814 \pm 98$ \\
\hline Ergotamine & $9.0 \pm 1.0$ & $3.0 \pm 0.4$ & $12 \pm 1.5$ \\
\hline Methysergide & $15.0 \pm 4.0$ & $9.1 \pm 4.9$ & $1.8 \pm 0.2$ \\
\hline Methylergonovine & $12.6 \pm 1.0$ & $0.49 \pm 0.16$ & $12.4 \pm 1.0$ \\
\hline Fluoxetine & $299 \pm 53$ & $5030 \pm 1960$ & $50 \pm 10$ \\
\hline Norfluoxetine & $638 \pm 108$ & $5063 \pm 1974$ & $286 \pm 60$ \\
\hline Trazodone & $19.8 \pm 2.4$ & $73.6 \pm 36$ & $402 \pm 44$ \\
\hline m-CPP & $391 \pm 47$ & $3.2 \pm 1.0$ & $59 \pm 11$ \\
\hline 5-HT & $614 \pm 74$ & $4.0 \pm 1.9$ & $12.2 \pm 1.3$ \\
\hline Phentermine & $>10,000$ & $>10,000$ & $>10,000$ \\
\hline
\end{tabular}

Values are mean $\pm S D$ for $n=3$ experiments. Data taken from ${ }^{39}$. 
Table 3

Functional Activity of Test Drugs at 5- $\mathrm{HT}_{2}$ Receptors.

\begin{tabular}{|c|c|c|c|}
\hline Drug & $\begin{array}{l}\text { Human 5-HT } 2 \text { Kact (nM } \\
\pm \text { SD) Vmax (Percent of 5-HT } \\
\pm \text { SD) }\end{array}$ & $\begin{array}{l}\text { Human } 5-\mathrm{HT}_{2 \mathrm{~B}} \text { Kact (nM } \\
\pm \mathrm{SD}) \text { Vmax (Percent of } 5 \text {-HT } \\
\pm \mathrm{SD})\end{array}$ & $\begin{array}{l}\text { Human } 5-\mathrm{HT}_{2 \mathrm{C}} \text { Kact }(\mathrm{nM} \pm \mathrm{SD}) \\
\text { Vmax (Percent of } 5-\mathrm{HT} \pm \mathrm{SD})\end{array}$ \\
\hline$( \pm)$-Fenfluramine & $\begin{array}{l}4131 \pm 2448 \\
15 \pm 4\end{array}$ & ND & ND \\
\hline (+)-Fenfluramine & $\begin{array}{l}>10,000 \\
\mathrm{ND}\end{array}$ & $\begin{array}{l}379 \pm 120 \\
38 \pm 14\end{array}$ & $\begin{array}{l}362 \pm 109 \\
80 \pm 10\end{array}$ \\
\hline (-)-Fenfluramine & $\begin{array}{l}5279 \pm 998 \\
43 \pm 7.2\end{array}$ & $\begin{array}{l}1248 \pm 430 \\
47 \pm 5\end{array}$ & $\begin{array}{l}360 \pm 155 \\
84 \pm 15 \%\end{array}$ \\
\hline$(+)$-Norfenfluramine & $\begin{array}{l}630 \pm 240 \\
88 \pm 9\end{array}$ & $\begin{array}{l}18.4 \pm 9 \\
73 \pm 6 \\
\end{array}$ & $\begin{array}{l}13 \pm 4 \\
100 \pm 11 \\
\end{array}$ \\
\hline$(-)$-Norfenfluramine & $\begin{array}{l}1565 \pm 323 \\
93 \pm 9\end{array}$ & $\begin{array}{l}357 \pm 180 \\
71 \pm 15\end{array}$ & $\begin{array}{l}18 \pm 9 \\
80 \pm 17\end{array}$ \\
\hline Ergotamine & $\begin{array}{l}16 \pm 4 \\
75 \pm 3 \\
\end{array}$ & $\begin{array}{l}9.8 \pm 3 \\
56+1-3 \\
\end{array}$ & $\begin{array}{l}5 \pm 3 \\
75 \pm 15 \\
\end{array}$ \\
\hline Methysergide & $\begin{array}{l}3.5 \pm-1.7 \\
24 \pm 3\end{array}$ & $\begin{array}{l}150 \pm 43 \\
18 \pm 4\end{array}$ & $\begin{array}{l}2.9 \pm 1.5 \\
33 \pm 3.5\end{array}$ \\
\hline Methylergonovine & $\begin{array}{l}1.3 \pm 0.4 \\
70 \pm 7\end{array}$ & $\begin{array}{l}0.8 \pm 0.5 \\
40 \pm 3\end{array}$ & $\begin{array}{l}2.5 \pm 1.2 \\
103 \pm 7\end{array}$ \\
\hline Fluoxetine & ND & ND & $\begin{array}{l}\text { Antagonist } \\
\mathrm{Ki}=616 \pm 172\end{array}$ \\
\hline Norfluoxetine & ND & ND & $\begin{array}{l}\text { Antagonist } \\
\mathrm{Ki}=43 \pm 17\end{array}$ \\
\hline Trazodone & Antagonist & Antagonist & Antagonist \\
\hline $\mathrm{m}-\mathrm{CPP}$ & $\begin{array}{l}65 \pm 17 \\
55 \pm 11\end{array}$ & $\begin{array}{l}64 \pm 27 \\
43 \pm 14 \\
\end{array}$ & $\begin{array}{l}0.64 \pm 0.3 \\
79 \pm 15\end{array}$ \\
\hline 5-HT & $\begin{array}{l}66 \pm 26 \\
100 \% \\
\end{array}$ & $\begin{array}{l}2.4 \pm 1.5 \\
100\end{array}$ & $\begin{array}{l}0.6 \pm 0.18 \\
100\end{array}$ \\
\hline Phentermine & ND & ND & $\begin{array}{l}1394 \pm 450 \\
66 \pm 10\end{array}$ \\
\hline
\end{tabular}

Values are mean $\pm \mathrm{SD}$ for $\mathrm{n}=3$ experiments. Data taken from ${ }^{39}$. 